Article

\title{
Citizen Scientists Showed a Four-Fold Increase of Lynx Numbers in Lithuania
}

\author{
Linas Balčiauskas ${ }^{1, * \mathbb{C}}$, Laima Balčiauskiene ${ }^{1}$, John A. Litvaitis ${ }^{2}$ and Eugenijus Tijušas ${ }^{3}$ \\ 1 Laboratory of Mammalian Ecology, Nature Research Centre, Akademijos 2, 08412 Vilnius, Lithuania; \\ laima.balciauskiene@gamtc.lt \\ 2 Department of Natural Resources and the Environment, University of New Hampshire, 105 Main Street, \\ Durham, NH 03824,USA; John.Litvaitis@unh.edu \\ 3 Lithuanian Hunters and Fishers Association, M. Sleževičiaus 15, 06326 Vilnius, Lithuania; \\ tijusaseugenijus@gmail.com \\ * Correspondence: linas.balciauskas@gamtc.lt; Tel.: +370-685-34141
}

Received: 31 October 2020; Accepted: 22 November 2020; Published: 23 November 2020

check for updates

\begin{abstract}
By the early 2000s, Eurasian lynx (Lynx lynx) were nearly extirpated in Lithuania. To determine their status, we used snow-track counts in 2006-2012 and volunteer monitoring in 1999-2005 and 2015-2018. Using simple questionnaires, we collected incidental observations from hunters, foresters, and other interested citizens to estimate lynx distribution, abundance and extent of breeding. Citizen scientists provided 206 reports of 278 individual lynx that suggested expanding lynx distributions in central, western, southwestern, and southern parts of Lithuania. A decrease in range fragmentation has also been observed since 2015. Nationwide, the lynx population quadrupled from 2010 to 162 individuals in 2018. The number of breeding individuals reported was just seven in both 2007 and 2008, limited to two forests in the very north and central part of the country. This increased to 46 in 2015-2018. Our results indicate that the lynx population in Lithuania has increased and its conservation status should be reconsidered.
\end{abstract}

Keywords: large carnivores; volunteer monitoring; threatened species

\section{Introduction}

Despite a general increase of large carnivore populations across Europe, there are likely differences among species. Eurasian lynx (Lynx $\operatorname{lynx}$ ), with an estimated total population of 9000 individuals in 2011, are associated with human-dominated landscapes and areas outside of protected reserves [1]. The most robust populations are in Fennoscandia and the European portion of Russia [2]. In other regions, populations are fragmented $[1,2]$ and face various challenges $[3,4]$, including limited acceptance and poaching [5].

Regional delineations of lynx populations have not been consistent. Historically, lynx in Lithuania were part of the Baltic population that included European Russia, Belarus, Ukraine, Estonia, Latvia, and Poland [6]. Currently, the Baltic population consists of Estonia, Latvia, Lithuania, and Poland [1]. This population is not, however, genetically distinct from populations in Finland and western Russia [7].

Compared to neighboring Latvia and Estonia, lynx in Lithuania are substantially less abundant and patchily distributed [1,2,6,8]. Baltic lynx populations differ north-to-south $[2,9,10]$, where they are highly fragmented in Lithuania, northern and western Belarus, and northeastern Poland. The Baltic population is estimated at 1500-2000 [1,2,11,12], with Latvia and Estonia supporting 90\% [13,14], whereas Lithuania and Poland support no more than $10 \%$ of these lynx [15]. In Estonia and Latvia, lynx are hunted (status = game animal), but in Lithuania and Poland, they are a protected species [11]. 
Full protection of lynx in Lithuania started in 1979 [16], and they have been included in the Red Data Book of Lithuania since 2000. Other efforts to protect lynx in Lithuania were: 2001—included in the list of the strictly protected animal species of community interest under the EU Habitats Directive [17], 2002-included in the list of animal and plant species of community interest that are present in Lithuania and whose protection requires designation of areas for protection of habitats [18], 2003 - included in the list of protected animals, plants, and fungi of the Republic of Lithuania [19], and 2004 to 2009-protected habitats were designated [20]. Until 2007, lynx were assigned category 3(R), a rare species. In 2007, the threat category was changed to 1(E), an endangered species. Since 2019, that threat category is no more assigned [19]. From 2011 to 2014, the Ministry of Environment implemented an EU funded project ("Captive Breeding of Lynx and Eagle Owls") that included the release of 17 captive-bred lynx into five locations of western and southwestern Lithuania. Five additional captive-bred animals were released between 2014 and 2017 [21].

Although information is scarce [9,22-24], the recent and current status of lynx in Lithuania warrants additional attention for appropriate conservation decisions. Therefore, the goals of this paper are to summarize information on lynx from 1995 to 2018 and present findings of a citizen-science effort that included lynx reports from 2015 to 2018. The main finding of this research was the proof of recovery of the lynx population from the 2007/2008 depression, including widening of species distribution, increase in numbers, documented increases in family groups, and increased geography of breeding in the country.

\section{Materials and Methods}

\subsection{Study Area}

Lithuania is a northern European country [25], with an area of $65,300 \mathrm{~km}^{2}$ (Figure 1a). Forests cover roughly $1 / 3$ of the country, and their extent increased from $33.1 \%$ in 2010 to $33.7 \%$ in 2019 [26]. Semi-natural vegetation covered $27 \%$, arable land $33 \%$ of the territory in 2012 [27], so in 2018, $52.26 \%$ of the country territory was referred to as agricultural [28]. The country is one of the most sparsely inhabited in the EU, with 52.9 inhabitants $/ \mathrm{km}^{2}$ in 2002 and 43.0 inhabitants $/ \mathrm{km}^{2}$ in 2018 [29]. Mammal diversity in the country is moderate, and the number of species increased from 68 in 2000 to 75 in 2020, carnivore fauna consists of 16 species [30,31]. Of these, the presence of the wild cat (Felis silvestris) is doubtful, brown bears (Ursus arctos) are possibly re-establishing with more frequent observations since 2015. Three carnivores, raccoon dogs (Nyctereutes procyonoides), American mink (Neovison vison), and raccoons (Procyon lotor) are allochthonous and invasive. Golden jackals (Canis aureus), first reported in 2015, are also allochtonous but not considered invasive [32]. Wolves (Canis lupus), Eurasian lynx, and brown bears are the largest carnivores in Lithuania [30]. 


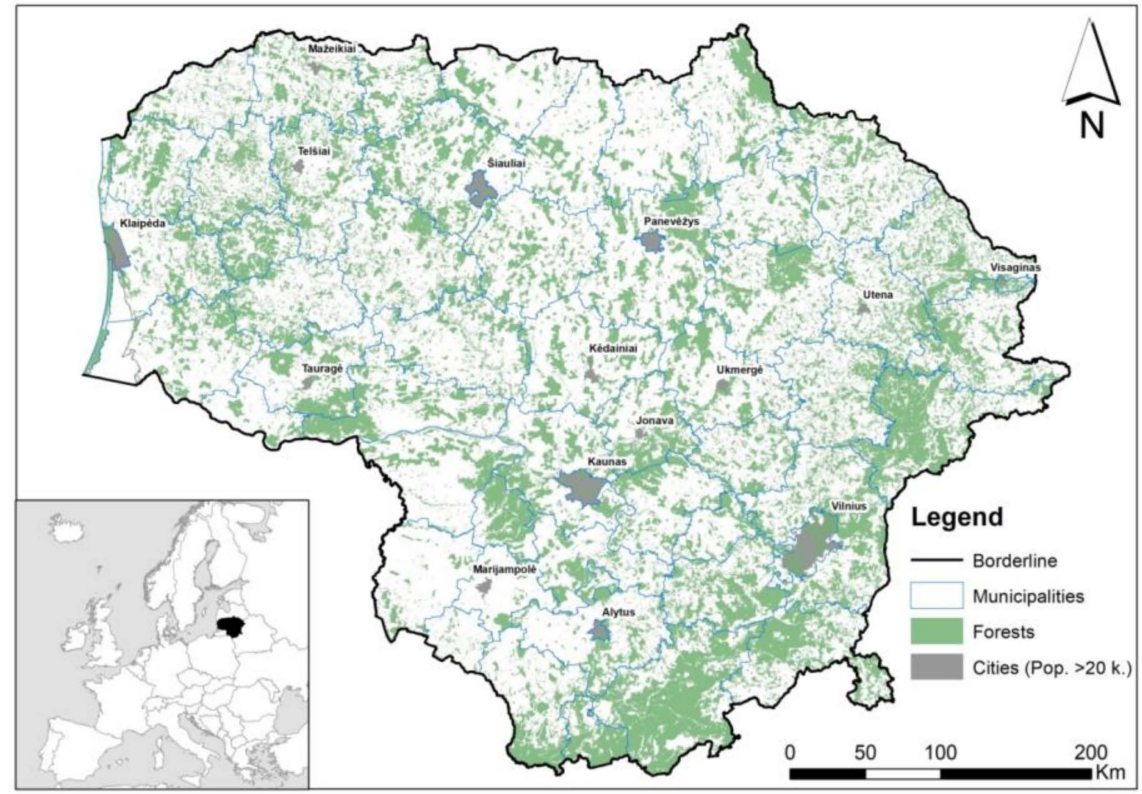

(a)

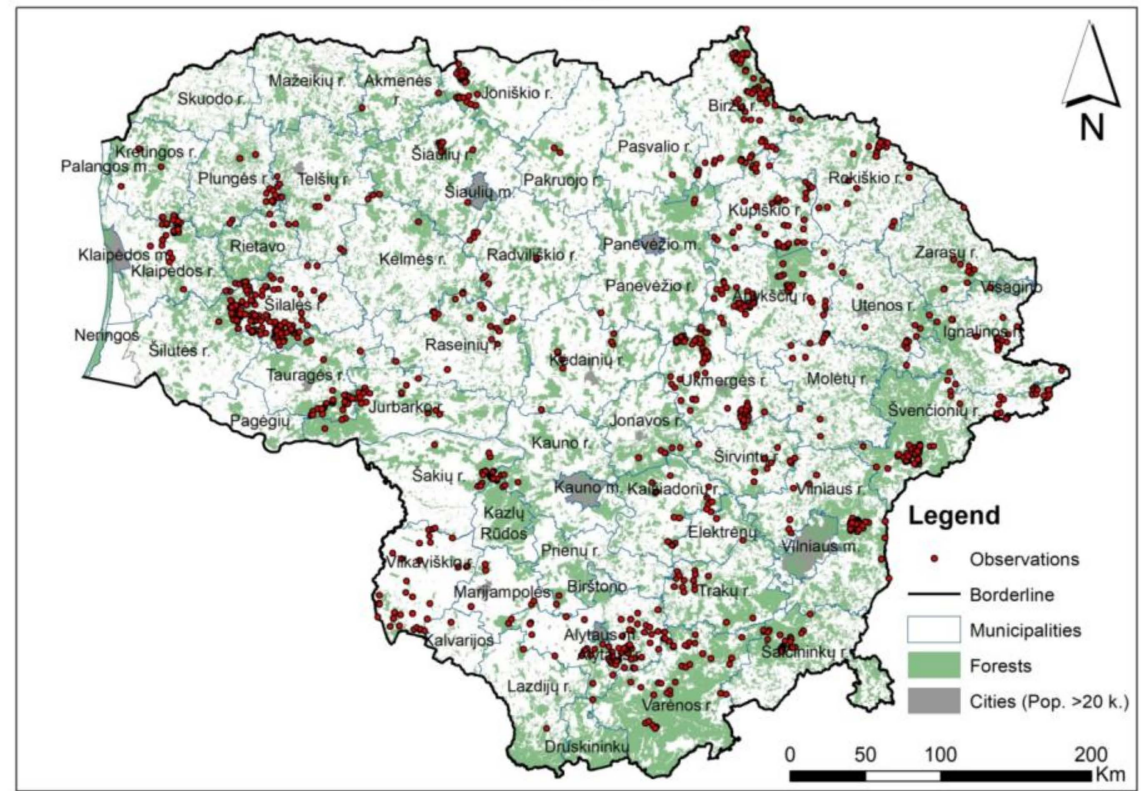

(b)

Figure 1. Forest cover in Lithuania, (a) inset showing country location and (b) representation of all received observations according to districts. Grayscale background indicates districts with insufficient observer coverage ( $0-5$ reports).

\subsection{Data Collection in Different Periods}

Lynx distribution was monitored from 1995 using several techniques. The first summary was the Atlas of Lithuanian Mammals, Amphibians and Reptiles [30] that presented a species distribution map based on observations in $10 \times 10-\mathrm{km}$ grid squares by foresters, hunters, and field researchers that spanned 1995 to 1999. In the next period, 2000 to 2005, we used information obtained via questionnaires from foresters in every forest-management district in the country. Based on direct observations and the field evidence (tracks, scats, or prey remains), forest districts were classified as occupied or not occupied. From 2006 to 2015, lynx presence was assessed using snow-track counts, conducted by cooperating foresters and hunters. Counts were coordinated and completed on the same day in all 427 (2006-2010) or 369 (2011-2012) forest districts and nature reserves across the country. Specific 10-12 km long 
transects were used in all areas. Potential double counts were excluded by comparing the number of tracks in neighboring transects. The number of lynx was estimated by tracks, as recommended in [33]. This method was limited by the presence of consistent snow cover. During the winters of 2013 to 2015 , patchy or limited snowfall prevented the use of track counts, so we designed an alternative method based on observations from the general public, hunters, foresters, farmers, and professional scientists.

\subsection{Citizen-Science Project for Large Carnivore Monitoring, 2015 to 2018}

After 2015, we used questionnaires to collect data (time and location) on all observations of lynx, including direct sighting, vocalization, or field evidence. Potential observers were recruited using various media channels, and questionnaires were constantly available on the websites of Nature Research Centre and Lithuanian Hunters and Fishers Association. The questionnaire structure is described in [34]. Out of 1295 reports received, 1220 fit into the analyzed time frame. Anonymous reports were not accepted and most reports contained photographic or video records in addition to questionnaires and were received via email. We contacted observers when necessary to obtain additional information or clarification. The staff of the Laboratory of Mammalian Ecology of the Nature Research Centre conducted nearly 100 crosschecks (by visiting reported locations or their environs) to ensure data quality.

\subsection{Index Evaluation and Statistics}

The number of the occupied forest districts, as an index of lynx distribution, was compared between sampling periods using chi-square tests. Lynx distribution, numbers observed, and the average number per observations were summarized by administrative districts [35]. Excluding urban municipalities, these sampling units $(\mathrm{n}=48)$ ranged from 440 to $2216 \mathrm{~km}^{2}$ (mean $=1282.2 \mathrm{~km}^{2}$ ). However, in 6 of 48 districts, no reports were obtained (Figure 1). To correct undersampling-based bias, we addressed missing records as recommended by Gonsamo and D'Odorico [36]. We used the official data of the lynx snow track counts in 2018 and 2019 [37] and compared these records to the lynx numbers in the pooled observations from volunteers obtained from 2015 to 2018. Snow-track counts were completed by cooperating hunters once per year in all hunting clubs [38] along designated 10-12 km transects. Lynx abundance in under-sampled municipalities was approximated using the linear regression equation generated from the relationship between snow-track counts in winter 2018 and municipalities with more than one report (Figure 1b). This enabled us to address missing records. Lynx abundance was estimated excluding possible redundant records. We excluded all reports that came from within a $10 \times 10-\mathrm{km}$ grid within the study period (for the workflow, see [34]). Proportions of different group sizes in the total sample were compared using a chi-square test. The minimum significance level was set at $p=0.05$.

All observation localities were mapped using coordinates, presented in photographic records or determined by observers using GPS devices. Maps were created using ESRI inc. ArcGIS Desktop ArcMap software and data, legally owned or used by Nature Research Centre. Calculations were done with Statistica for Windows, ver. 6.0 (StatSoft, Inc., Tulsa, OK, USA), and PAST, ver. 4.01 (Ø. Hammer, D.A.T. Harper, Oslo, Norway).

\section{Results}

\subsection{Changes in Lynx Distribution-1995 to 2018}

Lynx distribution in the country from 1995 to 2005 was in decline (Figure 2). In terms of inhabited forest districts, that number decreased from 85 (19.2\% of the total) in 1999 to $60-64$ (14.1-15.9\%) in 2002, 2004 and 2005, and $47(11.0 \%)$ in $2003\left(\chi^{2}=23.6, d f=6, p<0.0001\right)$. In line with a decreasing range, the population was concentrated in the northeastern part of the country, while in other regions, it became fragmented. Areas inhabited by lynx were not those most heavily afforested (see Figure 1). 

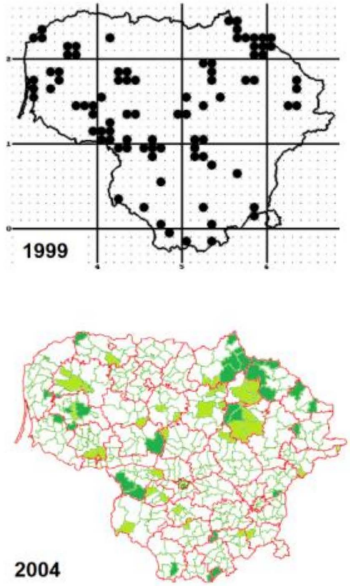
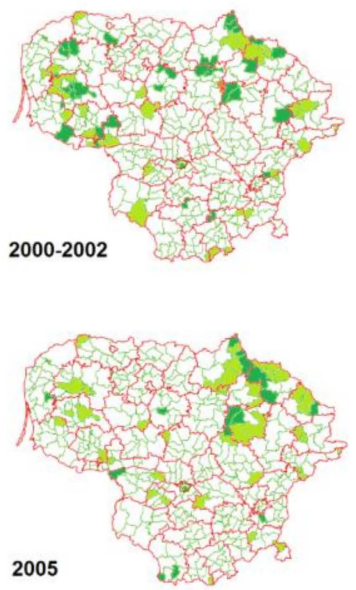
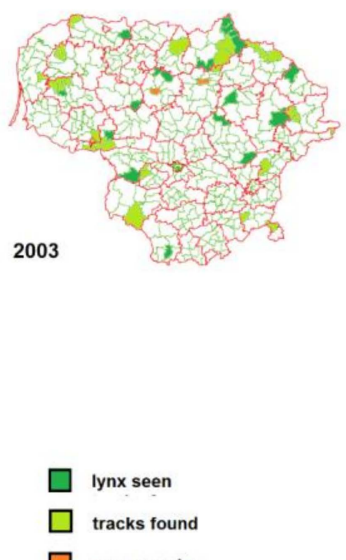

Figure 2. Lynx distribution in Lithuania from 1999 to 2005 based on the results of the voluntary observations. Map for 1999 is based on findings in $10 \times 10-\mathrm{km}$ grid cells, other maps are based on forester reports from forest districts where lynx were detected. Red lines denote boundaries of the forest enterprises, green lines show forest districts.

By 2006-2008, the distribution of lynx was substantially fragmented, including the core area in the northeastern part of the country (Figure 3). The number of inhabited forest districts decreased from 33 (7.7\% from the total) in 2006, to $20(4.7 \%)$ in 2007 and further to only $16(3.7 \%)$ in 2008 , being the worst years for lynx in Lithuania $\left(\chi^{2}=6.46, d f=2, p<0.05\right)$. By 2010 ( 25 sites, $\left.5.9 \%\right)$, the range of inhabited territories started to recover. In 2011, the number of the inhabited forest districts was $41(11.3 \%$ of the total), and 37 (10.2\%) in 2012. In 2013-2015, snow-track counts were not performed or were not effective, therefore, lynx distribution was not determined. However, it seems that the population started to recover during this period. Initially, the occupied range covered northeastern to central parts of the country. A network of inhabited fragments then started to form in the southern and western parts, characterized by larger forested areas (see Figure 1a).
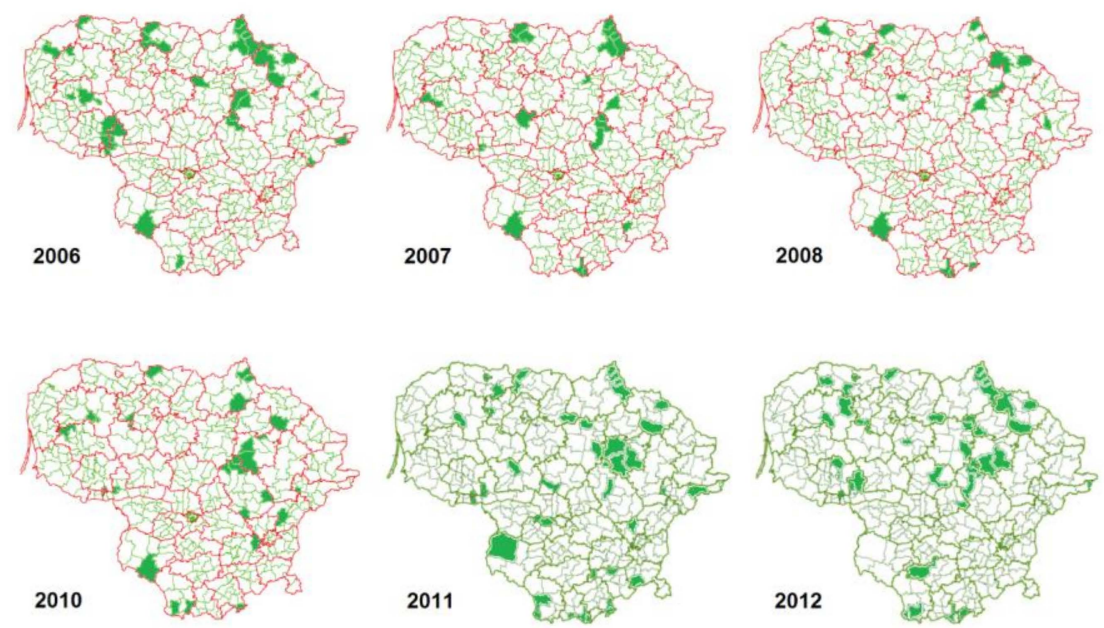

Figure 3. Lynx distribution in Lithuania from 2006 to 2013 based on results of the snow-track counts. Red lines denote boundaries of the forest enterprises in 2006-2010, thick green lines denote boundaries of the forest enterprises in 2011 and 2012 and thin green lines show forest districts. Note: From 2011, the number of the forest districts became less, as some were merged to increase their territory.

In 2015, monitoring by citizen scientists started. Those results showed an increase in the lynx range from 2015 to 2018, including new locations where single animals were reported (Figure 4). Additionally, the number and distribution of observed family groups also increased (including males with females 
in the breeding season and females with young). Volunteers provided 206 reports of lynx (in 94 cases direct animal sightings were reported, in 104 cases, lynx tracks were observed, and the remainder were based on prey remains and tracks, scats and tracks, and vocalizations). The total number of lynx observed was 278 , including those possibly recorded several times (Table S1). Single animal observations were 161 cases, 26 cases were pairs (a female with a kitten), in 11 cases, three individuals were observed, four cases with four individuals, and in two cases, five individuals were reported. One registration of five individuals was supported by video, all five individuals were tracking each other in a very short time period with heavy snowfall. Presumably, this was a female and four males.

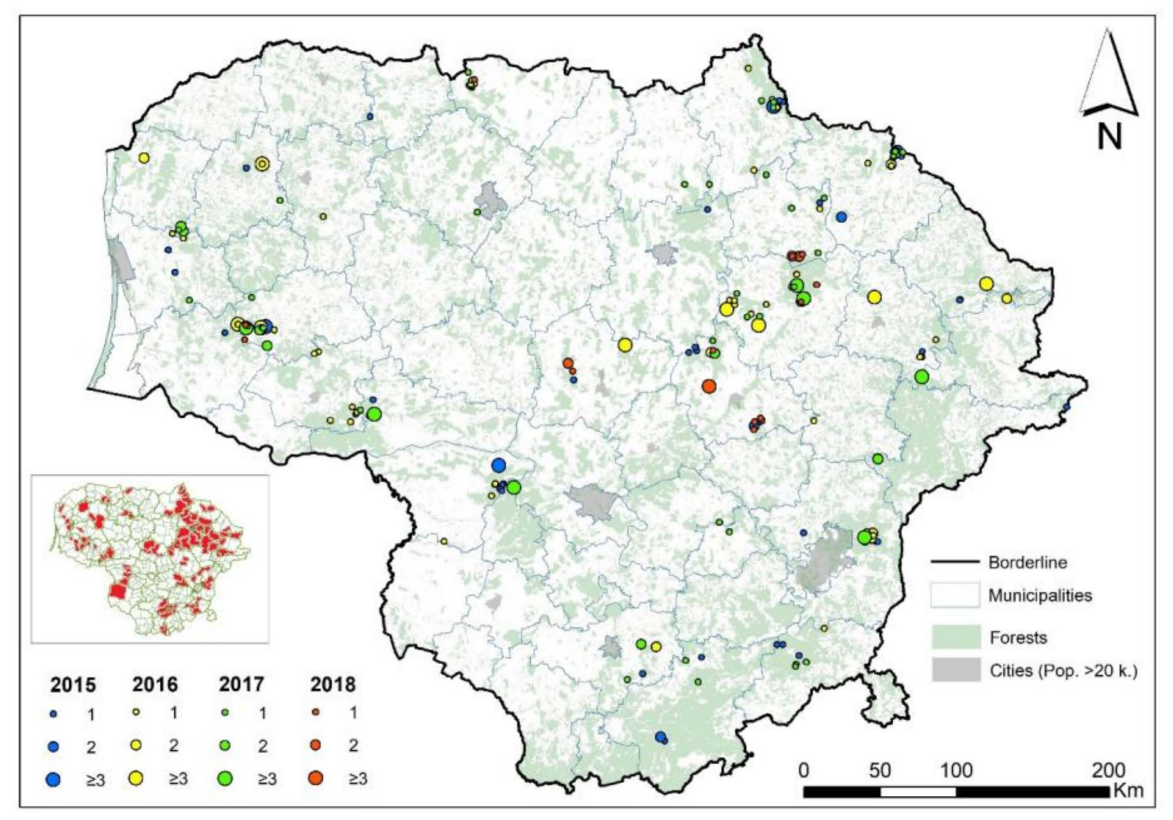

Figure 4. Lynx distribution in Lithuania from 2015 to 2018 based on results of volunteer observations. Inset shows lynx that inhabited forest districts. The number of registered individuals represented by circles of different size and years are denoted by color.

In 2015-2018, lynx distribution expanded to 77 forest districts (21.2\% of the total). Differences in the inhabited area from that reported in 2012 is significant $\left(\chi^{2}=12.16, d f=1, p=0.0005\right)$. Clusters of inhabited forest districts in the course of a few years occurred in the central, western, southwestern, and southern parts of the country, while the inhabited area in the northeastern region increased and became less fragmented (condensed view in the inset of Figure 4).

\subsection{Changes in Lynx Numbers-2003 to 2018}

In 2003 and 2004, lynx numbers were 19 and 32, respectively [24]. Snow-track surveys in 2007 and 2008 confirmed that the lynx population in Lithuania was very small (30-40 individuals) and characterized by the smallest distribution ever recorded (see Figure 3). In south and central Lithuania, lynx were nearly absent. In 2007, lynx numbers were estimated at 30, in 2010-2012 at 40, 50 , and 60 , respectively, all these numbers are based on the snow-track counts. Track counts were conducted in all forest districts and nature reserves simultaneously that spanned the entire country and the resulting estimates were considered minimums. In 2013 and 2014, track counts failed due to inconsistent snow coverage at the time of the surveys. Based on obtained reports in 2015-2018, with repeated observations deleted, 104 lynx were present in the districts with $>1$ observation (Table S1).

We compared the density of lynx tracks found in the winter survey of 2018 (TI, lynx track index per $1 \mathrm{~km}$ of survey route per one day after the last snowfall) to the number of lynx individuals registered by citizen scientists in $10 \times 10-\mathrm{km}$ grid squares in the same municipality (Table S1). This relationship was correlated $(r=0.61, F=11.82, d f=1,20, p=0.003)$ and well described by a linear regression 
(Figure 5). Based on this regression, we estimated the lynx numbers in under-sampled administrative districts. If that effort was consistent, an additional 58 individuals could have been observed (Table S1). With respect to under-represented regions where snow tracking showed lynx presence, the estimated nationwide lynx population was 162 individuals in 2018.

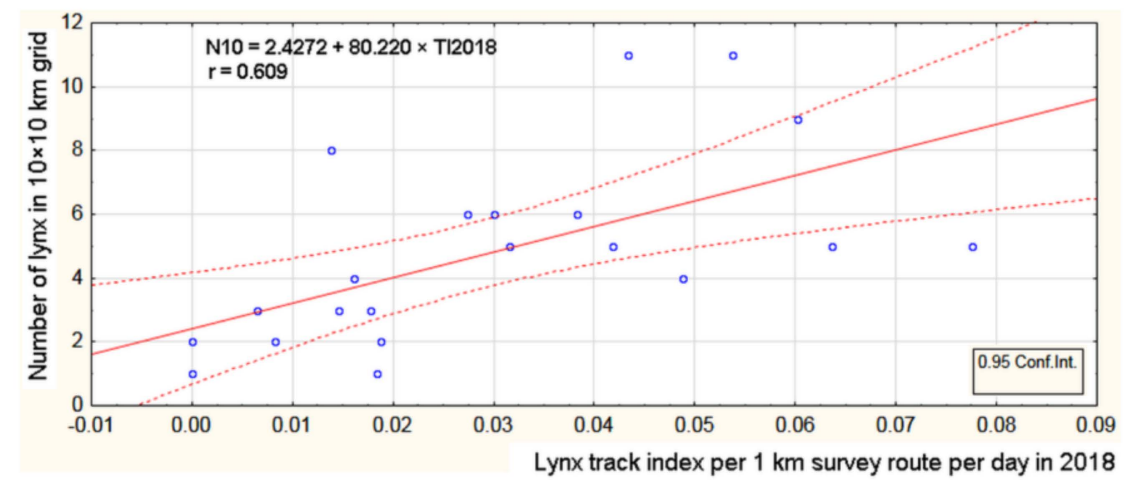

Figure 5. Relation of lynx numbers reported by citizen scientists from 2015 to 2018 per $10 \times 10-\mathrm{km}$ grid square to the average number of the lynx tracks during the winter of 2018. Dashed lines show $95 \%$ confidence of the regression line.

Among recent snow-track counts of (Table S1), average track indices increased, but not significantly. TI was $0.0189 \pm 0.003$ in 2018 and $0.0280 \pm 0.013$ in $2019(t=0.70, d f=102, p=0.48)$. In 2019, lynx were not found in six districts where they were present in 2018, however, lynx also occurred four new districts. In 16 districts, lynx presence was not confirmed by snow tracking in 2018 nor in 2019. However, in six districts lynx presence was reported by citizen scientists. In 2019, one of the districts had a track index that was nearly 20 times higher than in 2018, and nearly 30 times higher as the average for the country (Table S1). If this value is removed as an outlier, the number of lynx registered by citizen scientists in $10 \times 10-\mathrm{km}$ grid squares is still correlated with the track index $(\mathrm{r}=0.45, F=7.46$, $d f=1,29, p=0.01$.

\subsection{Observed Lynx Groups and Breeding Cases}

From 2007 to 2012, the proportion of single animals per observation decreased as the share of two or three individuals increased $\left(\chi^{2}=26.32, d f=4, p<0.001\right)$. Most of these observations were based on the snow-track counts. In 2015-2018, the first observations of four and five animals were reported (Figure 6a), based on direct observations, camera captures, and track counts. Increases in breeding cases were also identified. In 2007 and 2008, only seven cases were recorded in two forest areas in the very north and central part of the country (Figure 3). In 2015-2018, the number of family groups and pairs was 46 (Figure 6b), and breeding cases were registered in most of the territory investigated by citizen scientists (Figure 4).
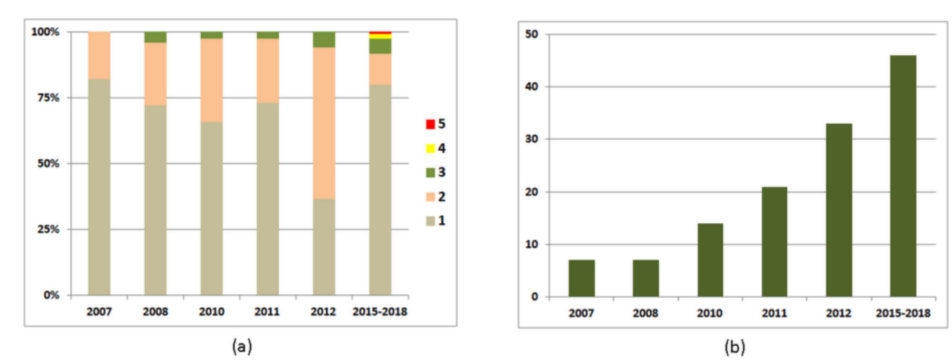

Figure 6. Distribution of the lynx numbers in observations (a), and the number of breeding cases (b) in 2007 to 2018. 


\section{Discussion}

Results of our citizen-science effort to monitor large carnivores in Lithuania have proven effective for wolves [34]. Here, we have presented results of the volunteer monitoring of lynx, including distribution, population size, and number of breeding cases. We found a considerable increase in lynx numbers. By 2018, we estimated a five-fold increase to 162 from the estimated minimum in 2007.

In earlier years of monitoring, overestimation of the lynx numbers may have been the result of using various sources of information with limited screening [22,23]. Reported lynx numbers were about 100 from 1993 to 2002, declined for several years, then increased (Table 1). These data were a summary of all submitted reports from hunting clubs without scrutiny of potential double counts. As a result, the actual population during these time periods (especially 2008-2020) was likely smaller.

Table 1. Lynx numbers in Lithuania from 1990 to 2020, according the data recorded by the Ministry of Environment of the Republic of Lithuania.

\begin{tabular}{ccccccccccccccc}
\hline Year & $\mathbf{1 9 9 0}$ & $\mathbf{1 9 9 1}$ & $\mathbf{1 9 9 2}$ & $\mathbf{1 9 9 3}$ & $\mathbf{1 9 9 4}$ & $\mathbf{1 9 9 5}$ & $\mathbf{1 9 9 6}$ & $\mathbf{1 9 9 7}$ & $\mathbf{1 9 9 8}$ & $\mathbf{1 9 9 9}$ & $\mathbf{2 0 0 0}$ & $\mathbf{2 0 0 1}$ & $\mathbf{2 0 0 2}$ & $\mathbf{2 0 0 6}$ \\
\hline Number & 170 & 150 & 123 & 106 & 104 & 100 & 110 & 106 & 96 & 81 & 87 & 103 & 111 & 69 \\
\hline Year & $\mathbf{2 0 0 7}$ & $\mathbf{2 0 0 8}$ & $\mathbf{2 0 0 9}$ & $\mathbf{2 0 1 0}$ & $\mathbf{2 0 1 1}$ & $\mathbf{2 0 1 2}$ & $\mathbf{2 0 1 3}$ & $\mathbf{2 0 1 4}$ & $\mathbf{2 0 1 5}$ & $\mathbf{2 0 1 6}$ & $\mathbf{2 0 1 7}$ & $\mathbf{2 0 1 8}$ & $\mathbf{2 0 1 9}$ & $\mathbf{2 0 2 0}$ \\
Number & 68 & 68 & 140 & 189 & 252 & 430 & 439 & 658 & 752 & 963 & 1038 & 1180 & 1305 & 1487 \\
\hline
\end{tabular}

We presumed that hunters and foresters are capable of carnivore monitoring large carnivores, so both groups were included in our citizen-scientist protocol. Such efforts are quickly developing for gathering information at large scales [39] and seem appropriate for monitoring large carnivores. This includes issues such as carnivore re-distribution following urbanization [40] and other specific questions [41,42]. Reed et al. [43] used volunteer observations to identify environmental features that operate at a large spatial scale (snowfall) and affect the regional distribution of bobcats (Lynx rufus). Participation in carnivore monitoring by rural residents can also reduce human-carnivore conflicts [44]. However, there are drawbacks of community-based monitoring [45], including the limitations of roving records [46].

In [34], we already proposed improvements to volunteer efforts, making data collection more effective: (1) To use hunting units as sampling units because these units are well known by volunteers, (2) to recruit volunteers for each sampling unit, (3) to advice for increased use of wildlife cameras, and (4) to restrict reporting period, thus reducing 'volunteer fatigue' and increasing reporting rates.

Results of citizen-science initiatives could also be used to establish conservation policies [47]. In Lithuania, the threat category of lynx has changed twice. In 2007, lynx were given the highest threat category due to minimum numbers found during snow-track counts (Dèl Lietuvos Respublikos saugomu gyvūnų, augalu ir grybu rūšiu sąrašo patvirtinimo), then, in 2019, the category was lessened in response to an apparent population increase [48]. In contrast to other species [49], over harvesting is not a threat to lynx in Lithuania.

Conservation policies and threats for the lynx in Lithuania were defined on the presumption that Lithuania and Poland are distinct from other populations in Europe [50]. Threats for lynx in Lithuania are similar to other countries and were defined as: (1) Geographic position on the edge of the distribution range, (2) lack of suitable habitats, (3) fragmentation of forests, (4) disturbance, (5) dietary competition with wolves and other carnivores, and (6) direct human influences, such as poaching and vehicle collisions [51]. Inbreeding within the small population may also be important [52]. Two of these threats (lack of suitable habitats and forest fragmentation) are addressed by the program of afforestation, started in 2002 [53]. Forest coverage in Lithuania has increased from 33.4\% to 33.7\% between 2014 and 2018 [54]. The increase in forest area, best expressed in eastern and northern parts of Lithuania, was 2.6\% from 1990 to 2018 [55]. We found that an increase in forest area has had a positive effect on moose (Alces alces) abundance [54]. However, for ungulates, forest fragments may provide increased access to food and cover [56]. For lynx, forest fragmentation may be related to greater lynx 
mortality at habitat edges [57]. Forest fragmentation is not easily managed or even recognized as having a negative influence on wildlife [58].

On the other hand, human influences, including hunting, poaching, and vehicle collisions can be addressed. However, protection may have unexpected adverse effects. For example, in Croatia, before lynx protection started in 1998, poaching accounted for 5\% of all deaths. From 1999 to 2013, poaching accounted for $60 \%$ of all deaths [59]. In Lithuania, two lynx were poached in $2009(6 \%$ of the population) and two poached plus two road killed in 2010 and 2011 (10\% of the population). One lynx was poached in both 2014 and 2015 in southern Lithuania, where the population was just starting to rebuild [51]. In general, increased lynx populations were followed by increased human-induced deaths $[60,61]$.

Acceptance of the lynx in Estonia, Lithuania, and Poland was greater than that of wolves. A south-to-north gradient was found in the knowledge of lynx abundance, their acceptance, and knowledge of management options [9]. Northern respondents tolerated a closer presence of carnivores near their homes. Estonian respondents preferred current population size or its reduction, while Lithuanian and Polish respondents preferred increasing the lynx population. In Lithuania, depending on the region, $56.4 \%-70.2 \%$ of respondents agreed to tolerate lynx no closer than $10 \mathrm{~km}$ from their homes, $22.8 \%-39.9 \%$ were for their reduction (including extermination). Most negative respondents were from northern Lithuania, where lynx are currently most abundant (see Figure 3, [9]). Fear and personal safety issues could be among the main drivers of the negative attitude toward lynx in Lithuania (e.g., [62]). Fear of lynx also exists in the other European countries [63-65], and that may be based on insufficient knowledge of the species [66].

We foresee further lynx population spread in Lithuanian, based on the number range expansion observed in 2019. The numbers of single animals reported in forest fragments of western, southern, and central Lithuania support the notion of an expanding population via dispersal. Negative attitudes towards further population growth among hunters may increase over concern for the effects of lynx on game populations. This has happened in other European countries (see [5,67]). Further increases in lynx abundance may also cause losses to sheep farms (the number of sheep kept in the country was over 150,000 in 2017-2020, [68]). Therefore, future concerns about the lynx conservation in Lithuania require developing a conservation policy based on population size, e.g., an agreement among stakeholders on the minimum viable population numbers, on the acceptable lynx numbers, and on possible species status change.

Supplementary Materials: The following are available online at http://www.mdpi.com/2071-1050/12/22/9777/s1, Table S1: Representativeness of citizen science data on lynx in Lithuania, 2015-2018, compared to official survey data, 2018-2019.

Author Contributions: Conceptualization, L.B. (Linas Balčiauskas) and J.A.L.; methodology, L.B. (Linas Balčiauskas) and J.A.L.; formal analysis, L.B. (Linas Balčiauskas); investigation, L.B. (Laima Balčiauskienė) and E.T.; writing-original draft preparation, L.B. (Linas Balčiauskas) and L.B. (Laima Balčiauskienè); writing-review and editing, J.A.L. and L.B. (Laima Balčiauskienè). All authors have read and agreed to the published version of the manuscript.

Funding: This research received no external funding.

Acknowledgments: We thank Andrius Kučas for GIS support of the project and maps.

Conflicts of Interest: The authors declare no conflict of interest.

\section{References}

1. Chapron, G.; Kaczensky, P.; Linnell, J.D.; von Arx, M.; Huber, D.; Andrén, H.; López-Bao, J.V.; Adamec, M.; Alvares, F.; Anders, O.; et al. Recovery of large carnivores in Europe's modern human-dominated landscapes. Science 2014, 346, 1517-1519. [CrossRef] [PubMed]

2. Von Arx, M.; Breitenmoser-Würsten, C.; Zimmermann, F.; Breitenmoser, U. (Eds.) Status and Conservation of the Eurasian Lynx (Lynx lynx) in Europe in 2001; KORA: Muri, Switzerland, 2004; pp. 1-319. 
3. Kubala, J.; Smolko, P.; Zimmermann, F.; Rigg, R.; Tám, B.; Il’ko, T.; Foresti, D.; Breitenmoser-Würsten, C.; Kropil, R.; Breitenmoser, U. Robust monitoring of the Eurasian lynx Lynx lynx in the Slovak Carpathians reveals lower numbers than officially reported. Oryx 2019, 53, 548-556. [CrossRef]

4. Port, M.; Henkelmann, A.; Schröder, F.; Waltert, M.; Middelhoff, L.; Anders, O.; Jokisch, S. Rise and fall of a Eurasian lynx (Lynx lynx) stepping-stone population in central Germany. Mammal Res. 2020, 1-11.

5. Červený, J.; Krojerová-Prokešová, J.; Kušta, T.; Koubek, P. The change in the attitudes of Czech hunters towards Eurasian lynx: Is poaching restricting lynx population growth? J. Nat. Conserv. 2019, 47, 28-37. [CrossRef]

6. Matyushkin, Y.N.; Vaisfeld, M.A. (Eds.) The Lynx-Regional Features of Ecology, Use and Protection. Game Animals of Russia and Adjacent Countries and Their Environment; Nauka: Moscow, Russia, 2003; p. 523.

7. Ratkiewicz, M.; Matosiuk, M.; Saveljev, A.P.; Sidorovich, V.; Ozolins, J.; Männil, P.; Balciauskas, L.; Kojola, I.; Okarma, H.; Kowalczyk, R.; et al. Long-Range Gene Flow and the Effects of Climatic and Ecological Factors on Genetic Structuring in a Large, Solitary Carnivore: The Eurasian Lynx. PLoS ONE 2014, 9, e115160. [CrossRef]

8. Prūsaitè, J. (comp.). Fauna of Lithuania. Mammals; Mokslas: Vilnius, Lithuania, 1988; pp. 214-218.

9. Balčiauskas, L.; Kazlauskas, M.; Randveer, T. Lynx acceptance in Poland, Lithuania, and Estonia. Est. J. Ecol. 2010, 59, 52-61. [CrossRef]

10. Ozolinšs, J.; Bagrade, G.; Ornicāns, A.; Žunna, A.; Done, G.; Stepanova, A.; Pilāte, D.; Šuba, J.; Lūkins, M.; Howlett, S.J. Action Plan for Eurasian Lynx Lynx lynx Conservation and Management; LSFRI Silava: Salaspils, Latvia, 2017; pp. 1-78.

11. Breitenmoser, U.; Breitenmoser-Würsten, C.; Okarma, H.; Kaphegyi, T.; Kaphygyi-Wallmann, U.; Ulrich, M.; Müller, U.M. Action Plan for the Conservation of the Eurasian Lynx (Lynx lynx) in Europe; Council and Europe Publishing: Strasbourg, France, 2000; pp. 1-69.

12. Boitani, L.; Alvarez, F.; Anders, O.; Andren, H.; Avanzinelli, E.; Balys, V.; Zlatanova, D. Key Actions for Large Carnivore Populations in Europe; European Commission: Bruxelles, Belgium, 2013; pp. 1-120.

13. Männil, P.; Kont, R. (comp.). Action Plan for Conservation and Management of Large Carnivores (Wolf Canis Lupus, Lynx Lynx lynx, Brown Bear Ursus Arctos) in Estonia in 2012-2021; Estonian Ministry of the Environment: Tallinn, Estonia, 2012; pp. 1-120.

14. Bagrade, G.; Runǵis, D.E.; Ornicāns, A.; Šuba, J.; Žunna, A.; Howlett, S.J.; Lūkins, M.; Gailīte, A.; Stepanova, A.; Done, G.; et al. Status assessment of Eurasian lynx in Latvia linking genetics and demography-A growing population or a source-sink process? Mammal Res. 2016, 61, 337-352. [CrossRef]

15. Status of Lynx Protection in Poland. Available online: https://carnivores.eu/lynx-2/in-poland/conservationstatus (accessed on 11 September 2020).

16. Dèl Lūšies $(\operatorname{Lyn} x \operatorname{lyn} x)$ Apsaugos Plano ir Veiksmų Planų Santraukų Patvirtinimo. Available online: https: //e-seimas.lrs.lt/portal/legalActPrint/lt?jfwid=bnp209k8m\&documentId=TAIS.423176\&category=TAD (accessed on 11 September 2020).

17. Europos Bendrijos Svarbos Gyvūnų Rūšių, Kurioms Reikalinga Griežta Apsauga, Sąrašas. Available online: https://e-seimas.lrs.lt/portal/legalAct/lt/TAD/TAIS.232329?jfwid=32wf6lrn (accessed on 11 September 2020).

18. Europos Bendrijos Svarbos Gyvūnų ir Augalų Rūšių, Randamų Lietuvoje, Kurioms Išsaugoti Reikia Steigti Buveinių Apsaugai Svarbias Teritorijas, Sarašas. Available online: https:/e-seimas.lrs.lt/portal/legalAct/lt/ TAD/TAIS.274251 (accessed on 11 September 2020).

19. Dèl Lietuvos Respublikos Saugomu Gyvūnų, Augalų ir Grybų Rūšių Sąrašo Patvirtinimo. Available online: https://e-seimas.lrs.lt/portal/legalActEditions/lt/TAD/TAIS.219902 (accessed on 11 September 2020).

20. èl Lietuvos Respublikos Aplinkos Ministro 2009 m. Balandžio 22 d. Isakymo nr. D1-210 “Dèl Vietovių, Atitinkančiu Gamtinių Buveinių Apsaugai Svarbiu Teritoriju Atrankos Kriterijus, Sąrašo, Skirto Pateikti Europos Komisijai, Patvirtinimo" Papildymo. Available online: https:/e-seimas.lrs.lt/portal/legalAct/lt/TAD/ TAIS.357756 (accessed on 11 September 2020).

21. Simanavičienè, M.; (State Service for Protected Areas under the Ministry of Environment, Vilnius, Lithuania). Personal Communication, 2020.

22. Bluzma, P. Estimation of the state of lynx and wolf populations in Lithuania. Acta Zool. Litu. 1999, 9, 35-41. [CrossRef]

23. Bluzma, P.; Baleišis, R. Monitoring of large carnivores in Lithuania: Experience and first results. In Proceedings of the BLCI Symposium "Human Dimensions of Large Carnivores in Baltic Countries", Šiauliai, Lithuania, 27-29 April 2001; Balčiauskas, L., Ed.; Akstis: Vilnius, Lithuania, 2001; pp. 55-63. 
24. Bukelskis, E.; Pètelis, K.; Tijušas, E. Cervids, wolf and lynx-census results. Hunt. Hunt. 2004, 3, 32-33.

25. UN Statistics Division. Geographic Regions. 2020. Available online: https://unstats.un.org/unsd/ methodology/m49/ (accessed on 15 October 2020).

26. Valstybinè Mišku Tarnyba. Oficialioji Statistika. 2020. Available online: http://www.amvmt.lt/index.php/ oficialioji-statistika (accessed on 15 October 2020).

27. European Environment Agency. Lithuania Land cover Country Fact Sheet. 2012. Available online: https://www.eea.europa.eu/ds_resolveuid/1ca731f33d0c48a0a4ed60abe67fa6bf (accessed on 16 March 2020).

28. National Land Service under the Ministry of Agriculture of the Republic of Lithuania. Available online: http://www.nzt.lt/go.php (accessed on 12 April 2020).

29. Lietuvos Statistikos Departamentas. Gyventojai. 2020. Available online: https://osp.stat.gov.lt/gyventojai1 (accessed on 12 April 2020).

30. Balčiauskas, L.; Trakimas, G.; Juškaitis, R.; Ulevičius, A.; Balčiauskienè, L. Atlas of Lithuanian Mammals, Amphibians and Reptiles, 2nd ed.; Akstis: Vilnius, Lithuania, 1999; p. 78.

31. Lietuvos Žinduoliu Atlasas. Available online: http://www.gamtostyrimai.lt/lt/users/viewGroup/id.24/pageId. 26 (accessed on 13 July 2020).

32. Stratford, J. Golden jackal in Lithuania, a consideration of its arrival, impact and status. Zool. Ecol. 2015, 25, 277-287. [CrossRef]

33. Balčiauskas, L.; Baranauskas, K.; Ferenca, R.; Gudžinskas, Z.; Gurskas, A.; Ivinskis, P.; Kesminas, V.; Ložys, L.; Rimšaitè, J.; Sinkevičienè, Z.; et al. Europos bendrijos svarbos rūšiu monitoringo metodikos. Žinduoliai, žuvys, varliagyviai, ropliai, moliuskai, vabzdžiai ir augalai; Gamtos Tyrimu Centras, Valstybinè Saugomu Teritoriju Tarnyba prie Aplinkos Ministerijos: Vilnius, Lithuania, 2016; pp. 10-19.

34. Balčiauskas, L.; Balčiauskienè, L.; Litvaitis, J.A.; Tijušas, E. Adaptive monitoring: Using citizen scientists to track wolf populations when winter-track counts become unreliable. Wildl. Res. 2020. [CrossRef]

35. Teritorijos Administracinis Suskirstymas. Available online: https://osp.stat.gov.lt/regionine-statistika-pagalstatistikos-sritis (accessed on 25 July 2020).

36. Gonsamo, A.; D'Odorico, P. Citizen science: Best practices to remove observer bias in trend analysis. Int. J. Biometeorol. 2014, 58, 2159-2163. [CrossRef] [PubMed]

37. Žveriu Apskaita. Available online: https://vstt.lrv.lt/lt/veiklos-sritys/biologines-ivairoves-apsauga/zveriuapskaita (accessed on 25 July 2020).

38. Dèl Lietuvos Respublikos Aplinkos Ministro 2000 m. Birželio 27 d. Isakymo Nr. 258 “Dèl Medžioklès Lietuvos Respublikos Teritorijoje Taisykliu Patvirtinimo“ Pakeitimo. Available online: https://www.e-tar.lt/ portal/legalAct.html?documentId=ca3dabf0d2d011e8bea9885f77677ec1 (accessed on 25 June 2020).

39. Eitzel, M.V.; Cappadonna, J.L.; Santos-Lang, C.; Duerr, R.E.; Virapongse, A.; West, S.E.; Kybs, C.C.M.; Bowser, A.; Cooper, C.B.; Sforzi, A.; et al. Citizen Science Terminology Matters: Exploring Key Terms. Citiz. Sci. Theory Pract. 2017, 2, 1-20. [CrossRef]

40. Parsons, A.W.; Rota, C.; Forrester, T.; Baker-Whatton, M.C.; McShea, W.J.; Schuttler, S.G.; Millspaugh, J.J.; Kays, R. Urbanization focuses carnivore activity in remaining natural habitats, increasing species interactions. J. Appl. Ecol. 2019, 56, 1894-1904. [CrossRef]

41. Granroth-Wilding, H.; Primmer, C.; Lindqvist, M.; Poutanen, J.; Thalmann, O.; Aspi, J.; Harmoinen, J.; Kojola, I.; Laaksonen, T. Non-invasive genetic monitoring involving citizen science enables reconstruction of current pack dynamics in a re-establishing wolf population. BMC Ecol. 2017, 17, 44. [CrossRef]

42. Skrbinšek, T.; Luštrik, R.; Majić-Skrbinšek, A.; Potočnik, H.; Kljun, F.; Jelenčič, M.; Kos, I.; Trontelj, P. From science to practice: Genetic estimate of brown bear population size in Slovenia and how it influenced bear management. Eur. J. Wildl. Res. 2019, 65, 29. [CrossRef]

43. Reed, G.C.; Litvaitis, J.A.; Ellingwood, M.; Tate, P.; Broman, D.J.A.; Sirén, A.P.K.; Carroll, R.P. Describing habitat suitability of bobcats (Lynx rufus) using several sources of information obtained at multiple spatial scales. Mamm. Biol. 2017, 82, 17-26. [CrossRef]

44. Ronnenberg, K.; Habbe, B.; Gräber, R.; Strauß, E.; Siebert, U. Coexistence of wolves and humans in a densely populated region (Lower Saxony, Germany). Basic Appl. Ecol. 2017, 25, 1-14. [CrossRef]

45. Conrad, C.C.; Hilchey, K.G. A review of citizen science and community-based environmental monitoring: Issues and opportunities. Environ. Monit. Assess. 2010, 176, 273-291. [CrossRef] 
46. Vercayie, D.; Herremans, M. Citizen science and smartphones take roadkill monitoring to the next level. Nat. Conserv. 2015, 11, 29-40. [CrossRef]

47. Levin, P.S.; Williams, G.D.; Rehr, A.; Norman, K.C.; Harvey, C.J. Developing conservation targets in social-ecological systems. Ecol. Soc. 2015, 20, 6. [CrossRef]

48. Balčiauskas, L.L.; Lietuvos Raudonoji Knyga. (Nature Research Centre, Vilnius, Lithuania). Personal Communication, 2020. in press.

49. Krofel, M.; Treves, A.; Ripple, W.J.; Chapron, G.; Lopez-Bao, J.V. Hunted carnivores at outsized risk. Science 2015, 350, 518-519. [CrossRef] [PubMed]

50. Breitenmoser, U.; Breitenmoser-Würsten, C.; Lanz, T.; von Arx, M.; Antonevich, A.; Bao, W.; Avgan, B. Lynx lynx (errata version published in 2017). The IUCN Red List of Threatened Species 2015: E.T12519A121707666. Available online: https://www.iucnredlist.org/species/12519/121707666 (accessed on 12 October 2020).

51. Gamtos Tyrimu Centras. Europos Bendrijos Svarbos Rūšių Būklès ir Invazinių Augalų ir Gyvūnų Rūšiu Tyrimu Atlikimo Paslaugos Ataskaita. 2015. Available online: http://gamta.lt/files/ataskaitaVII.doc (accessed on 10 May 2020).

52. LIFE Lynx. Lynx Populations. 2020. Available online: https://www.lifelynx.eu/populations/ (accessed on 10 September 2020).

53. Dèl Lietuvos Miškingumo Didinimo Programos Patvirtinimo. 2002. Available online: https://e-seimas.lrs.lt/ portal/legalAct/lt/TAD/TAIS.198062/iLjdpUFMOX (accessed on 10 May 2020).

54. Balčiauskas, L.; Kawata, Y.; Balčiauskienè, L. Moose Management Strategies under Changing Legal and Institutional Frameworks. Sustainability 2020, 12, 8482. [CrossRef]

55. European Environment Agency. Corine Land Cover 1990, Version 2020_20u1. Available online: https://land. copernicus.eu/pan-european/corine-land-cover/clc-1990?tab=metadata (accessed on 17 September 2020).

56. Reimoser, F.; Gossow, H. Impact of ungulates on forest vegetation and its dependence on the silvicultural system. Forest Ecol. Manag. 1996, 88, 107-119. [CrossRef]

57. Kowalczyk, R.; Górny, M.; Schmidt, K. Edge effect and influence of economic growth on Eurasian lynx mortality in the Białowieża Primeval Forest, Poland. Mammal Res. 2015, 60, 3-8. [CrossRef]

58. Rochelle, J.A.; Lehmann, L.A.; Wisniewski, J. (Eds.) Forest Fragmentation: Wildlife and Management Implications; Brill NV: Leiden, The Netherlands, 1999; pp. 1-322.

59. Sindičić, M.; Gomerčić, T.; Kusak, J.; Slijepčević, V.; Huber, Đ.; Frković, A. Mortality in the Eurasian lynx population in Croatia over the course of 40 years. Mamm. Biol. 2016, 81, 290-294. [CrossRef]

60. Ypatingai Saugomą lūšl Nušovusiam Medžiotojui Gresia Kalejjimas. Available online: https://www.15min.lt/naujiena/aktualu/nusikaltimaiirnelaimes/ypatingai-saugoma-lusi-nusovusiammedziotojui-gresia-kalejimas-59--1066132 (accessed on 17 September 2020).

61. Kauno Kriminalistai Sulaikè Lūšis Medžiojusius Pasieniečius: žala Siekia 20 Tūkst. eurų. Available online: https://www.15min.lt/naujiena/aktualu/nusikaltimaiirnelaimes/kauno-kriminalistai-sulaike-lusismedziojusius-pasieniecius-zala-siekia-20-tukst-euru-59--906296 (accessed on 17 September 2020).

62. Isidrąsinusios Lūšys ne Juokais Išgąsdino Kaimo Gyventojus: Neliko Nieko Kito Kaip Jas Sugauti. Available online: https:/www.delfi.lt/grynas/gamta/isidrasinusios-lusys-ne-juokais-isgasdino-kaimogyventojus-neliko-nieko-kito-kaip-jas-sugauti.d?id=85485375 (accessed on 29 October 2020).

63. Bath, A.; Olszanska, A.; Okarma, H. From a human dimensions perspective, the unknown large carnivore: Public attitudes toward Eurasian lynx in Poland. Hum. Dimens. Wildl. 2008, 13, 31-46. [CrossRef]

64. Johansson, M.; Ferreira, I.A.; Støen, O.G.; Frank, J.; Flykt, A. Targeting human fear of large carnivores-Many ideas but few known effects. Biol. Conserv. 2016, 201, 261-269. [CrossRef]

65. Lopes-Fernandes, M.; Frazão-Moreira, A. Relating to the wild: Key actors' values and concerns about lynx reintroduction. Land Use Policy 2017, 66, 278-287. [CrossRef]

66. Lescureux, N.; Linnell, J.D.C.; Mustafa, S.; Melovski, D.; Stojanov, A.; Ivanov, G.; Avukatov, V.; von Arx, M.; Breitenmoser, U. Fear of the unknown: Local knowledge and perceptions of the Eurasian lynx Lynx lynx in western Macedonia. Oryx 2011, 45, 600-607. [CrossRef] 
67. Lopes-Fernandes, M.; Espírito-Santo, C.; Frazão-Moreira, A. The return of the Iberian lynx to Portugal: Local voices. J. Ethnobiol. Ethnomed. 2018, 14, 3. [CrossRef] [PubMed]

68. Oficialiosios Statistikos Portalas. Gyvulininkystè. 2020. Available online: https://osp.stat.gov.lt/statistiniurodikliu-analize?hash=627e6385--1020--4bac-b100--16df658328af\#/ (accessed on 14 October 2020).

Publisher's Note: MDPI stays neutral with regard to jurisdictional claims in published maps and institutional affiliations.

(C) 2020 by the authors. Licensee MDPI, Basel, Switzerland. This article is an open access article distributed under the terms and conditions of the Creative Commons Attribution (CC BY) license (http://creativecommons.org/licenses/by/4.0/). 